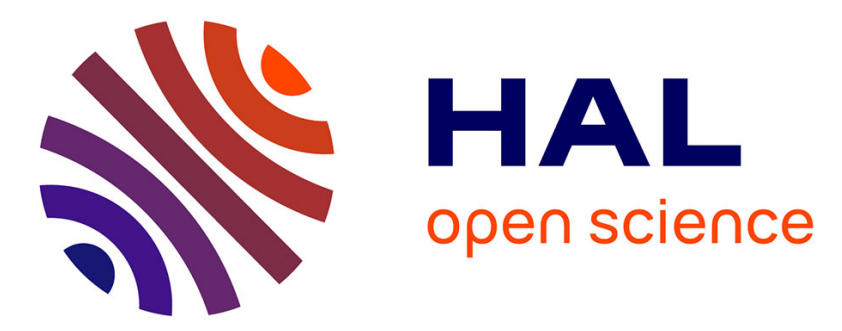

\title{
In vitro toxicity assessment of extracts derived from sol-gel coatings on polycarbonate intended to be used in food contact applications
}

Isabelle Séverin, Krystelle Lionti, Laurence Dahbi, Catherine Loriot, Bérangère Toury, Marie-Christine Chagnon

\section{To cite this version:}

Isabelle Séverin, Krystelle Lionti, Laurence Dahbi, Catherine Loriot, Bérangère Toury, et al.. In vitro toxicity assessment of extracts derived from sol-gel coatings on polycarbonate intended to be used in food contact applications. Food and Chemical Toxicology, 2016, 93, pp.51 - 57. 10.1016/j.fct.2016.04.025 . hal-01434899

\section{HAL Id: hal-01434899 \\ https://u-bourgogne.hal.science/hal-01434899}

Submitted on 13 Apr 2021

HAL is a multi-disciplinary open access archive for the deposit and dissemination of scientific research documents, whether they are published or not. The documents may come from teaching and research institutions in France or abroad, or from public or private research centers.
L'archive ouverte pluridisciplinaire HAL, est destinée au dépôt et à la diffusion de documents scientifiques de niveau recherche, publiés ou non, émanant des établissements d'enseignement et de recherche français ou étrangers, des laboratoires publics ou privés. 


\section{In vitro toxicity assessment of extracts derived from sol-gel coatings on polycarbonate intended to be used in food contact applications.}

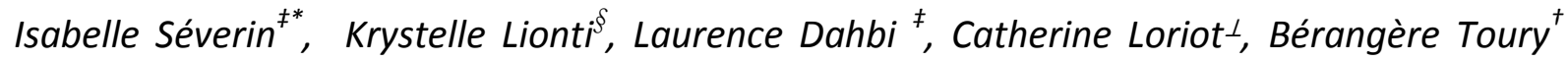
and Marie-Christine Chagnon ${ }^{\ddagger}$

' Laboratoire des Multimatériaux et Interfaces UMR 5615, University of Lyon, Villeurbanne 69100, France.

${ }^{\S}$ IBM Almaden Research Center, San Jose, California 95120, USA.

${ }^{\perp}$ Laboratoire National de Metrologie et d'essais, Trappes 78197, France.

‡ Derttech « Packtox » LNC UMRU866, Nutox Team, Agrosupdijon, Université BourgogneFranche-Comté Dijon 21000, France.

*Corresponding Author: Phone: +(33) 3807740 38, Email: isabelle.severin@agrosupdijon.fr

KEYWORDS: Ames test, micronucleus assay, endocrine disruption, HepG2 cell line, sol-gel coating, food contact coating, polycarbonate, migration, extracts

\section{ABBREVIATIONS}

BNC: binucleated cell, FBS: fetal bovine serum, FCM: food contact materials, GPTES: 3glycidyloxypropyltriethoxysilane, IF: induction factor, MEM: minimum essential medium, $\mathrm{MN}$ : micronucleus, MTES: triethoxymethylsilane, PBS: phosphate buffered saline, OECD: organization for economic co-operation and development, TEOS: tetraethylorthosilicate. 


\section{ABSTRACT}

Polycarbonate is a widely used polymer in food contact applications all around the world. However, due to the potential release of Bisphenol A (BPA) during repeated washing cycles, its use becomes compromised as BPA is known for being an endocrine disruptor for rodents. In order to tackle this issue, sol gel coatings based on organoalkoxysiloxane were developed on PC, to act as a physical barrier. To this end, two solegel systems based on tetraethylorthosilicate (TEOS), methyltriethoxysilane (MTES) and 3glycidyloxypropyltriethoxysilane (GPTES), three common solegel precursors, were prepared. The coatings derived from the latter two systems were then studied with regards to their potential toxicity in vitro. Migration tests were performed in food simulants, and the maximal migration was obtained in ethanol $10 \%(\mathrm{v} / \mathrm{v})$ for one system and in isooctane for the other one. In vitro genotoxicity was assessed with the Ames test (OECD 471) and the micronucleus assay (OECD 487), and no genotoxic effect was observed. Moreover, the estrogenic activity of the extracts was studied with a transcriptional activation assay using transient transfection in human cells; none of the extracts was found estrogenic. These negative in vitro results are highly promising for the future use of these new barrier coating formulations onto food contact materials.

\section{INTRODUCTION}

Polycarbonate (PC) is a widely used polymer in a variety of applications such as electronics, optics, automobile or even construction, which clearly shows the diversity of the use of the PC (over two million tons produced each year). As a food grade material, PC is also very present in the alimentary field (bottles, containers...), the latter benefiting from its transparency, lightness and exceptional impact resistance at a reasonable cost ${ }^{1}$. Unfortunately, PC displays poor scratch and solvent resistance along with a fairly high sensitivity to hydrolysis, which significantly limit the polymer's lifetime. In addition, the potential release of bisphenol A (BPA), a component monomer of PC, is currently of toxicological concern. It is worth pointing out that while the use of BPA in food contact materials is permitted in the European Union (EU) under Regulation (EU) No 10/2011 ${ }^{2}$, it became restricted in January 2011 when the European Commission adopted regulation (EU) No $321 / 2011 / \mathrm{EU}^{3}$, that prohibits to use PC in infant feeding bottles manufacturing. 
To mitigate PC hydrolysis, thus BPA release, one could envision modifying PC's bulk directly, with the aim of achieving higher chemical stability. Although no such studies are reported in the literature, it is well-known that loading specific additives during PC formulation ${ }^{4}$, or preparing PC copolymers ${ }^{5,6}$ can successfully tune PC properties. However, these compositional modifications typically impact other useful properties of the material as well. Another path to achieve the same is surface modification via the deposition of protective films: barrier coatings with improved mechanical properties (as compared to raw PC) could largely increase PC's lifetime and fully prevent BPA release, maintaining PC suitable in food contact applications.

In that regard, dense oxide-like barrier coatings are excellent candidates as high mechanical properties can be obtained using industry-compatible techniques such as Plasma-Enhanced Chemical Vapor Deposition (PECVD) ${ }^{7}$, Diamond-Like Carbon (DLC) deposition $^{8}$, plasma-ion assisted deposition ${ }^{9}$, atmospheric plasma ${ }^{10}$ or the sol-gel route ${ }^{11-14}$. Due to the rapid, low-cost and easy to implement nature of the latter technique, we focused our efforts on the preparation of hybrid silica coatings by sol-gel, on PC. ORMOSILS (organically modified silica, i.e. class II hybrid O/I silica precursors), which display a nonhydrolysable $\mathrm{Si}-\mathrm{C}$ bond ensuring chemical linkage between inorganic and organic networks, were used as starting precursors ${ }^{15}$. ORMOSILs particularly fit our specifications well due to the dual nature of hybrid $\mathrm{O} / \mathrm{I}$ silica, the latter offering elevated hardness and resistance through the inorganic part, as well as softness/flexibility or even specific characteristics (hydrophobia, anti-microbial resistance...) through the organic one. It is worth noting that, among the commercially available ORMOSILs, only ethoxy-ending precursors (as opposed to methoxy-ending ones) were used in the sol preparation, in order to release ethanol (harmless) as a sol-gel secondary product rather than methanol (highly toxic).

Here, we report on the toxicological testing of coatings derived from two different ORMOSILs based sols, with optimized mechanical properties and adhesion ${ }^{11,12}$. It is noteworthy to point out that chemical and mechanical properties of sol-gel coatings are widely reported in the literature, but toxicology testing, which is of primary importance for food contact applications, is hardly ever carried out and reported. Since many parameters can be adjusted when making sol-gel formulations, potentially leading to coatings with different composition, structure, and properties, the compliance with the European commission regulation of each sol-gel coating derived from a specific set of sol-gel 
conditions, intended to be used in food contact applications, needs to be evaluated. Our first formulation is based on triethoxymethylsilane (MTES). Although numerous patents already report on the deposition of similar coatings for alimentary applications ${ }^{16-18}$, the nature of the substrate was different (metallic substrate) and no toxicological data were included. The second sol is based on glycidyloxypropyltriethoxysilane (GPTES) and tetraethylorthosilicate (TEOS): the possibility of using GPTES in coatings for food-contact applications was only mentioned twice before, in our previous patent ${ }^{19}$ where no toxicology study had been intended to be conducted, and in our paper published two years ago where we only looked at the toxicity of GPTES as a starting precursor (i.e. unreacted) ${ }^{20}$.

In this paper, coatings extracts derived from the two above mentioned sol-gel formulations were collected and tested, as they contain all the substances susceptible to migrate from the material to the food simulant, i.e. intentionally added substances (IAS) but also non-intentionally added substances (NIAS). Genotoxicity is the prerequisite steps required by EFSA irrespective of the migration level of the substance intended to be used in contact with food ${ }^{21}$. This paper reports the data obtained from the Ames test performed according to the OECD 471 guideline with both coatings extracts in order to detect genetic mutations in bacteria. A second genotoxicity test, the micronucleus assay, also part of the tests required by EFSA, was performed according to the OECD 487 guideline on a human hepatoma cell line (HepG2 cells) in order to detect abnormalities on structure or in the number of chromosomes. In addition, estrogenic activity of the coatings were also tested with an in vitro estrogen receptor transcriptional activation (ERTA) assay which identifies chemicals that are able to activate the estrogen receptor (ER $\alpha$ ) (i.e., ER agonists) on the human HepG2 cell line.

\section{MATERIALS ANS METHODS}

\subsection{Chemicals and medium}

Tetraethylorthosilicate (TEOS, $\mathrm{n}^{\circ} \mathrm{CAS}:$ 78-10-4), triethoxymethylsilane (MTES, $\mathrm{n}^{\circ} \mathrm{CAS}$ : 2031-67-6), 3-glycidyloxypropyltriethoxysilane (GPTES, $n^{\circ} \mathrm{CAS}:$ 2602-34-8), Ludox AS-30 (colloidal silica, 30 wt\% solid content, suspension in $\mathrm{H}_{2} \mathrm{O}$ ), glacial acetic acid, dimethylsulfoxyde (DMSO), cytochalasin B, all the positive controls (2-nitrofluorene (2-NF), sodium azide (SA), ICR191, 4-nitroquinoline-N-oxide (4-NQO), 2-aminoanthracene (2-AA), cyclophosphamide (CP), vinblastine sulfate (VBS), Minimum Eagle's medium (MEM) and 
100X non-essential amino acids were purchased from Sigma-Aldrich (Saint-QuentinFallavier, France) and used without any further purification. L-glutamin (200 mM), heatinactivated fetal bovine serum (FBS), phosphate-buffered saline without $\mathrm{Ca}^{2+}$ and $\mathrm{Mg}^{2+}(\mathrm{PBS})$ and trypsin (0.05\%)-EDTA $(0.02 \%)$ solution were obtained from Invitrogen laboratories (Cergy-Pontoise, France). Levasil 200E (colloidal silica, 20 wt\% solid content, suspension in $\mathrm{H}_{2} \mathrm{O}$ ) was generously given by Akzo Nobel. Isopropanol was purchased from VWR. $2 \mathrm{~mm}$ thick Bisphenol A-PC sheets, (molded from Mitsubishi's Lupilon S3000 UR pellets) were degreased with ethanol. A $\mathrm{N}_{2} / \mathrm{H}_{2}$-plasma treatment (atmospheric pressure, $\mathrm{N}_{2} / \mathrm{H}_{2}$ flow rate $330 \mathrm{~mm} / \mathrm{s}$ ), was performed on the PC substrate coated with GPTES and TEOS in order to increase the coating to substrate adhesion.

\subsection{Coatings synthesis}

Two different sol syntheses were done; all the steps were carried out at room temperature. MTES or (GPTES + TEOS) were mixed with acetic acid (referred to as solutions 1 and 1', respectively). Ludox AS30 or levasil 200E and isopropanol were mixed together under stirring (solutions 2 and 2' respectively). Solution 1 was then added to solution 2 (1+2 being referred to as $A 2$ thereafter), and solution $1^{\prime}$ added to solution $2^{\prime}\left(1^{\prime}+2^{\prime}\right.$ being referred to as A8 thereafter), under stirring. Finally, the sols (liquid state) were left aside under stirring for $48 \mathrm{~h}$ to ensure full hydrolysis, and were then deposited by dip-coating (withdrawal speed of $1 \mathrm{~mm} / \mathrm{s}$ ) on $10 \mathrm{~cm} \times 7.5 \mathrm{~cm} \times 2 \mathrm{~mm}$ PC sheets. A2 was deposited on PC substrates degreased with ethanol; $A 8$ was deposited on $\mathrm{N}_{2} / \mathrm{H}_{2}$ plasma treated $P C$ substrates. Following deposition, the coated specimens were annealed at $135 \mathrm{C}$ in a ventilated oven to cure them and obtain dense hybrid silica films (solids). A final film thickness of $\sim 4 \mu \mathrm{m}$ was measured by profilometry for both systems.

\subsection{Migration tests}

The overall migration tests were carried out according to either the European standard NF EN 1186-3 for the aqueous food simulants or the European standard NF EN 1186-14 §3 for isooctane or ethanol $95 \%$ substitute simulants. The test conditions were selected in accordance with the European standard NF ISO 1186-1: i) 1 hour at $100{ }^{\circ} \mathrm{C}$ for acetic acid $3 \%$ and ethanol $10 \%$, ii) 3 hours at $60^{\circ} \mathrm{C}$ for ethanol $95 \%$, and iii) 1 hour at $60^{\circ} \mathrm{C}$ for isooctane. 
Coated PC sheets of $0.5 \mathrm{dm}^{2}$ were placed in glass Petri dishes and immersed in $100 \mathrm{ml}$ of the substitute food simulants under well-defined time and temperature exposure conditions. To ensure the contact of the two faces of the plate with the simulants, a metallic stand was employed. In each food simulant, three replicates of the coated PC sheets as well as two blanks were tested. At the end of the test period, each PC sheet was removed from the substitute food simulant. Then, the food simulant was evaporated to dryness, the mass of the non-volatile residue was determined gravimetrically and expressed as $\mathrm{mg} / \mathrm{dm}^{2}$ of the surface area of the PC sheet.

The overall migration data is reported as the mean of three determinations on separate test PC sheets. The maximum authorized level is $10 \mathrm{mg} / \mathrm{dm}^{2}$ with an analytical deviation of 2 $\mathrm{mg} / \mathrm{dm}^{2}$ for the aqueous and substitute simulants.

\subsection{Sample preparation for toxicity tests}

For each system (A2 and A8), the migration extract showing the highest level of migration (most stringent experimental conditions) were used to perform the subsequent toxicity tests: for $A 2$, the isooctane simulant in contact with $A 2$ coated PC sheets was evaporated to dryness and the dried migration extract was then dissolved in $1 \mathrm{~mL}$ of ethanol $95 \%(\mathrm{v} / \mathrm{v})$. The extract was concentrated 100 fold as ethanol (the vehicle for bioassays) is used at the final concentration of $1 \%$ in the culture medium. At higher concentration, ethanol is cytotoxic for the HepG2 cell line. For $A 8$, the ethanol $10 \%(v / v)$ simulant in contact with A8 coated PC sheets was evaporated to dryness and the dried migration extract was then dissolved in $1 \mathrm{~mL}$ ethanol $10 \%(\mathrm{v} / \mathrm{v})$, and concentrated 100 fold as well. Each extract in ethanol was then directly added to the culture medium. The final tested concentrations were $13.5 \mathrm{mg} / \mathrm{mL}$ and $41.5 \mathrm{mg} / \mathrm{mL}$ for $\mathrm{A} 2$ and $\mathrm{A} 8$ extracts, respectively. However, bacteria used in the Ames test being more resistant than human cells, the final concentration of ethanol in the agar was $3.8 \%$ instead of $1 \%$. Thus, the maximal concentrations tested of $A 2$ and $A 8$ extracts in the Ames test were $51.3 \mathrm{mg} / \mathrm{mL}$ and $157.73 \mathrm{mg} / \mathrm{mL}$, respectively.

\subsection{Metabolic activation system}

S9 fraction, prepared from male Sprague-Dawley rats, dosed with phenobarbital and 5,6benzoflavone to stimulate mixed-function oxidases in the liver, was purchased from Trinova Biochem (Giessen, Germany). 
The S9 mix presents in the bacterial mutation assay consisted of $10 \%(\mathrm{v} / \mathrm{v})$ S9 fraction, $33 \mathrm{mM}$ potassium chloride $(\mathrm{KCl}), 8 \mathrm{mM}$ magnesium chloride $\left(\mathrm{MgCl}_{2}\right), 4 \mathrm{mM}$ nicotinamide adenine dinucleotide phosphate (NADP) and $5 \mathrm{mM}$ glucose-6-phosphate (G-6-P) prepared in $100 \mathrm{mM}$ phosphate buffer (PBS, $\mathrm{pH}$ 7.4).

For the in vitro mammalian cell micronucleus assay, the $\mathbf{S 9}$ mix presents in the culture medium (final concentration during treatment) consisted of $2 \%(\mathrm{v} / \mathrm{v}) \mathrm{S} 9$ fraction, $5 \mathrm{mM}$ G-6$P, 0.3 \mathrm{mM}$ NADP, $1.5 \mathrm{mM} \mathrm{KCl}^{22}$.

\subsection{Bacterial reverse mutation test}

The plate incorporation method with or without metabolic activation was conducted according to Maron and $A m e s^{23}$ and the OECD guidelines for the testing of chemicals $n^{\circ} 471$. The histidine-requiring Salmonella typhimurium strains TA98, TA100, TA135 and TA1537 were obtained from Dr. Bruce Ames (Berkeley, USA). The tryptophan-requiring Escherichia coli strain WP2uvrA (pKM101) was provided from Trinova Biochem (Giessen, Germany). The test strains were cultured in Oxoid nutrient broth $\mathrm{n}^{\circ} 2$ for $10 \mathrm{~h}$ at $37^{\circ} \mathrm{C}$ under agitation.

$A$ range of $A 2$ and $A 8$ extracts concentrations was selected (25-50-100 $\mu \mathrm{l} / \mathrm{plate}$ ) for the study. In the presence or absence of metabolic activation, each concentration of test substances was conducted in triplicate. The reference mutagens used as positive controls were as followings: 2-NF (2 $\mu \mathrm{g} /$ plate) for TA98, SA (1 $\mu \mathrm{g} / \mathrm{plate})$ for TA100 and TA1535,

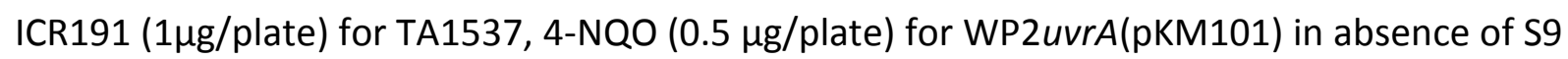
mix and 2-AA (2.5 $\mu \mathrm{g} /$ plate) for TA98, TA100, TA1535 and TA1537, 2-AA (25 $\mu \mathrm{g} / \mathrm{plate})$ for WP2uvrA (pKM101) in presence of S9 mix. The mutagenic activities were expressed as induction factors, i.e. as multiples of the background levels of the negative controls.

The test substance is considered positive in a bacterial reverse mutation assay when there is (a) an increase ( $\geq$ twofold number for TA98, TA100 and WP2uvrA(pKM101) or $\geq$ threefold number for TA1535 and TA1537) of spontaneous revertants comparing with those of negative control or (b) a dose-dependent increase of revertants colonies in at least one of the tester strains without cytotoxicity.

\subsection{In vitro micronucleus test in HepG2 cells}

The micronucleus test was conducted in accordance to OECD guidelines for the testing of chemicals $n^{\circ} 487$. The HepG2 cell line was obtained from the ECACC (European Collection of 
Cell Culture, UK). Routine monitoring has shown the HepG2 cells to be mycoplasma free (Mycoalert kit from Cambrex, Verviers, France). The cells were grown in monolayer culture in MEM supplemented with $2 \mathrm{mM} \mathrm{L-glutamine,} \mathrm{1 \%} \mathrm{non-essential} \mathrm{amino} \mathrm{acids} \mathrm{and} 10 \% \mathrm{FBS}$ in a humidified atmosphere of $5 \% \mathrm{CO}_{2}$ and at $37^{\circ} \mathrm{C}$. Continuous cultures were maintained by sub-culturing flasks every 7 days at $2.2 \times 10^{6}$ cells $/ 75 \mathrm{~cm}^{2}$ flask by trypsination during 10 passages.

The HepG2 cells were seeded at $5 \times 10^{5}$ cells/well in a 6-wells microplate and incubated overnight. The cells were treated with $A 2$ and $A 8$ extracts dissolved respectively in ethanol $95 \%$ and ethanol $10 \%$ (final concentration in culture medium 1\%) for $4 \mathrm{~h}$ with S9mix and for $24 \mathrm{~h}$ without S9mix. Vinblastine $(0.625 \mathrm{ng} / \mathrm{ml})$ and mitomycine $C(25 \mathrm{ng} / \mathrm{ml})$ were used as positive controls without S9 $\operatorname{mix}(24 \mathrm{~h}$ treatment) and cyclophosphamide $(10 \mu \mathrm{g} / \mathrm{ml})$ with S9 mix ( $4 \mathrm{~h}$ treatment). At the end of the treatment, the cells were washed and fresh medium containing cytochalasine $B(4 \mu \mathrm{g} / \mathrm{mL})$ was added for $44 \mathrm{~h}$.

All treatments were duplicated at each concentration. Approximately 1 hour prior to harvest, the cultures were rinsed with PBS, refed with MEM medium, and returned to the incubator for an additional hour. Then, the cells were trypsinized, fixed with a methanol:acetic acid solution ((3:1 v/v), and spotted on glass slide and stained with acridine orange $(0.1 \%)$ diluted in Sorensen Buffer $(1 / 15, v / v)$ just before microscopic analysis.

The cytotoxicity was evaluated by the cytokinesis-block proliferative index (CBPI). $\mathrm{CBPI}=$ [(number of cells with 1 nucleus $\times 1)+($ number of cells with 2 nuclei $\times 2)+($ number of cells with greater than 2 nuclei $\times 3)$ ] / total number of cells scored. The cytotoxicity was determined by using the following formula: Cytotoxicity = $100-100$ [(CBPI treated culture -1$)$ / (CBPI vehicle control culture -1)].

Micronucleus frequencies were analyzed in at least 2000 binucleated cells per concentration (at least 1000 binucleated cells from each culture). For the identification of micronuclei, the criteria of Kirsch-Volders et $a .^{24}$ were applied: micronuclei should have a diameter less than one-third of the main nucleus, they should be clearly distinguishable from the main nucleus and they should have the same staining than the main nucleus. The data were analyzed by one-way ANOVA followed by Student Newman-Keuls test and the differences were considered significant for $p<0.05$.

\subsection{Transcriptional activation assay for estrogenic effect}


HepG2 cells were transiently transfected, as previously described by Gasnier et al. ${ }^{25}$, using the Exgen 500 procedure. Briefly, the wells of 24 -well plates were seeded with $0.125 \mathrm{x}$ $10^{6}$ cells/well in MEM supplemented with $2 \mathrm{mM}$ L-glutamine, $1 \%$ non-essential amino acid and $10 \%$ dextran-coated charcoal-treated FBS. Cells were transfected 24 hours after plating, with 500 ng plasmid per well (100 ng pRST7-hER $\alpha, 100$ ng ERE-TK-Luc, 100 ng pCMV $\beta$ Gal and $200 \mathrm{ng}$ pSG5) first mixed with $2 \mu \mathrm{l}$ Exgen 500 in $30 \mu \mathrm{l}$ of $0.15 \mathrm{M} \mathrm{NaCl}$. After 1 hour, the transfection medium was removed and replaced with $1 \mathrm{ml}$ of treatment medium. MEM without phenol red, $2 \mathrm{mM}$ glutamine; $1 \%$ non-essential amino acid and without fetal calf serum in presence of ethanol extracts $(13.5 \mathrm{mg} / \mathrm{mL}$ for $A 2$ and $41.5 \mathrm{mg} / \mathrm{mL}$ for $A 8)$ for $24 \mathrm{~h}$. 17-b-estradiol was used as positive control at $10 \mathrm{nMwhich}$ is the saturating agonist concentration resulting in the maximal response in the bioassay.

At the end of the treatment, cells were lysed with Reporter Lysis Buffer (Promega) and frozen at $-80{ }^{\circ} \mathrm{C}$ for at least $30 \mathrm{~min}$. They were then scraped and placed into microtubes before three freezing (liquid nitrogen)/thawing $\left(37^{\circ} \mathrm{C}\right.$ waterbath) cycles and centrifuged 5 $\min$ at $10,600 \times$ g.

The resulting lysates were used to determine luciferase and bgalactosidase activities, together with protein levels, as described by Gasnier et al. $^{25}$. For luciferase activity measurement, $10 \mathrm{~mL}$ of lysate were mixed with $50 \mathrm{~mL}$ of luciferase assay reagent (Promega) into a white 96-well plate. The mixtures were immediately analyzed using a luminometer (TopCount NT, Packard). The $\beta$-Galactosidase activity was measured using chlorophenolred-D-galactopyranoside (Roche Diagnostics GmbH, Mannheim, Germany). The chlorophenol-red product was measured with a spectrophotometer at $570 \mathrm{~nm}$ (MRX Dynex). Protein concentration determination was performed using $2 \mathrm{~mL}$ of the lysate according to Bradford (1976) method on a spectrophotometer at $595 \mathrm{~nm}$. The luciferase activity was normalized against $\beta$-galactosidase activity and protein contents. The induction was compared to the negative control.

\section{RESULTS}

\subsection{Migration test}

Under the defined analytical conditions and provided that the constituents of the PC sheets are allowed by the food contact European regulation, the overall migration in aqueous and substitute simulants of both $A 2$ and $A 8$ coated PC sheets were below the limits 
set up by the regulation on plastics materials intended to come into contact with food (10 $\mathrm{mg} / \mathrm{dm}^{2}$ ). The highest result of migration was obtained either for the A2 coated PC sheet in the isooctane simulant $\left(2.7 \mathrm{mg} / \mathrm{dm}^{2}\right)$ or for the A8 coated-PC sheet in the $10 \%$ ethanol simulant $\left(8.3 \mathrm{mg} / \mathrm{dm}^{2}\right)$. (see Table 1). Assuming an average film thickness of $4 \mathrm{~mm}$ and a density of $1.65 \mathrm{~g} / \mathrm{cm} 3$ for both coatings (previously measured by X-ray-reflectivity), these values correspond to a weight loss of $\sim 4 \%(w / w)$ for $A 2$ coating, and $\sim 13 \%$ (w/w) for $A 8$ coating.

Table 1. Results of experimental migration data of $A 2$ and $A 8$ extracts, expressed in $\mathrm{mg} / \mathrm{dm}^{2}$.

\begin{tabular}{|l|l|l|l|}
\hline A2 formulation & Food simulants & Individual values & Mean $\left(\mathbf{m g} / \mathbf{d m}^{2}\right)$ \\
\hline $1 \mathrm{~h}, 100^{\circ} \mathrm{C}$ & Acetic acid $3 \%$ & $0.7 ; 1.0 ; 0.5$ & 0.7 \\
\hline $1 \mathrm{~h}, 100^{\circ} \mathrm{C}$ & $10 \%$ ethanol & $0.9 ; 0.3 ; 0.8$ & 0.7 \\
\hline $3 \mathrm{~h}, 60^{\circ} \mathrm{C}$ & $95 \%$ ethanol & $0.3 ; 1.6 ; 0.8$ & 0.9 \\
\hline $1 \mathrm{~h}, 60^{\circ} \mathrm{C}$ & Isooctane & $1.1 ; 2.3 ; 4.8$ & 2.7 \\
\hline $1 \mathrm{~h}, 100^{\circ} \mathrm{C}$ & Olive oil & $1.0 ; 0.2 ; 0.2$ & $<1$ \\
\hline $\mathbf{A 8}$ formulation & Food simulants & Individual values & Mean $\left(\mathbf{m g} / \mathbf{d m}^{2}\right)$ \\
\hline $1 \mathrm{~h}, 100^{\circ} \mathrm{C}$ & Acetic acid $3 \%$ & $2.6 ; 6.8 ; 1.1$ & 3.5 \\
\hline $1 \mathrm{~h}, 100^{\circ} \mathrm{C}$ & $10 \%$ ethanol & $6.1 ; 16.2 ; 2.7$ & 8.3 \\
\hline $3 \mathrm{~h}, 60^{\circ} \mathrm{C}$ & $95 \%$ ethanol & $4.1 ; 1.1 ;<0.1$ & 1.8 \\
\hline $1 \mathrm{~h}, 60^{\circ} \mathrm{C}$ & Isooctane & $0.3 ; 0.1 ;<0.1$ & 0.2 \\
\hline $1 \mathrm{~h}, 100^{\circ} \mathrm{C}$ & Olive oil & $0.4 ; 0.8 ; 11.7$ & 4 \\
\hline
\end{tabular}

\subsection{Ames test}

The results of the Ames test (with/without exogenous metabolic activation) were validated by the presence of negative and positive controls included in the historical values of the laboratory. As expected, the respective positive control of each strain produced a significant mutagenic response (Table 2 and 3). The number of revertants was more than twofold for TA98 (33.6 without S9, 43.8 with S9), TA100 (9.6 without S9, 10.1 with S9) and WP2uvrA (pKM101) (>13 without S9, >5.7 with S9) and threefold for TA1535 (47.5 without S9, 12.1 with S9) and TA1537 (77.3 without S9, 19.4 with S9). 
Neither A2 nor A8 extracts were mutagenic for the bacteria compared to the respective negative controls even at the highest concentration tested $(51.3 \mu \mathrm{g} / \mathrm{mL}$ for $\mathrm{A} 2$ and 157.73 $\mu \mathrm{g} / \mathrm{mL}$ for $\mathrm{A} 8$ ), the induction factor never exceeds 2 , irrespective of the conditions tested (Table 2 and 3).

Table 2. Results of Ames test data obtained with the strain TA98, TA 100, TA 1535, TA 1537 and E. Coli WP2 uvra pKM101 of three concentrations of A2 extract, tested with and without exogenous activation system and expressed as revertants/plate and induction factors (i.e. multiple of negative control).

\begin{tabular}{|l|c|c|c|c|c|c|c|c|c|c|}
\hline Sample & \multicolumn{2}{|c|}{ TA 98 } & \multicolumn{3}{c|}{ TA 100 } & \multicolumn{3}{c|}{$\begin{array}{c}\text { TA 1537 1535 } \\
\text { E. Coli W2, uvra, } \\
\text { pKM 101 }\end{array}$} \\
\hline & $\begin{array}{c}\text { Revertants } \\
\text { plate }\end{array}$ & $\begin{array}{c}\text { Induction } \\
\text { factor }\end{array}$ & $\begin{array}{c}\text { Revertants } \\
\text { plate }\end{array}$ & $\begin{array}{c}\text { Induction } \\
\text { factor }\end{array}$ & $\begin{array}{c}\text { Revertants } \\
\text { plate }\end{array}$ & $\begin{array}{c}\text { Induction } \\
\text { factor }\end{array}$ & $\begin{array}{c}\text { Revertants } \\
\text { plate }\end{array}$ & $\begin{array}{c}\text { Induction } \\
\text { factor }\end{array}$ & $\begin{array}{c}\text { Revertants } \\
\text { plate }\end{array}$ & $\begin{array}{c}\text { Induction } \\
\text { factor }\end{array}$ \\
\hline
\end{tabular}

Table 3. Results of Ames test data obtained with the strain TA98, TA 100, TA 1535, TA 1537 and E. Coli WP2 uvra pKM101 of three concentrations of A8 extract, tested with and without exogenous activation system and expressed as revertants/plate and induction factors (i.e. multiple of negative control).

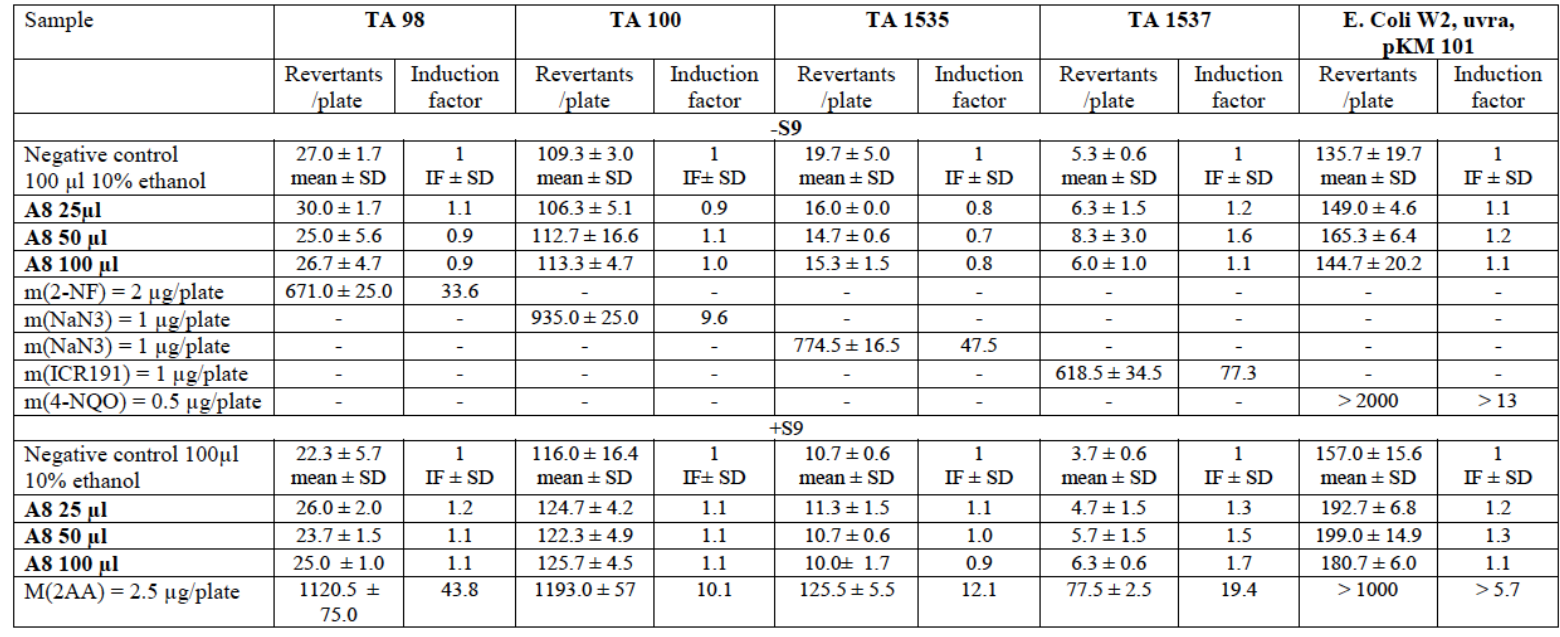




\subsection{Micronucleus assay}

The number of micronulei per 1000 binucleated cells (MN/1000 BNC) was assessed as a measure of chromosomal abnormalities in the micronucleus assay when HepG2 cells were exposed to 0.5 or $1 \%$ of the ethanol extract. In the presence of enzymatic activities (+S9mix) and after a $4 \mathrm{~h}$ exposure of HepG2 cells, with the clastogenic reference cyclophosphamide $(10 \mu \mathrm{g} / \mathrm{ml})$, an increase of MN was observed with $58 \mathrm{MN} / 1000 \mathrm{BNC}$ instead of $17 \mathrm{MN} / 1000$ BNC for the negative control. In absence of metabolic enzymes (S9mix), the positive aneugenic control (vinblastine sulfate, $0.625 \mathrm{ng} / \mathrm{ml}$ ) induced a clear positive effect with 63 $\mathrm{MN} / 1000 \mathrm{BNC}$ compared to the negative control (19 MN/1000 BNC). The clastogenic control (mitomycine C $25 \mathrm{ng} / \mathrm{ml}$ ) gave, as expected, an increase of the number of micronuclei (194 $\mathrm{MN} / 1000 \mathrm{BNC}$ ). Irrespective of the conditions of treatment (short or long), no cytotoxic effect was observed on any extract. A2 and A8 extracts did not induce any chromosomal aberrations in the HepG2 cell line (Table 4).

Table 4. Percentage of cytotoxicity and number of micronuclei/1000 binucleated cells in HepG2 cells after a short or a long time of exposure to $A 2$ and $A 8$ extracts.

\begin{tabular}{|c|c|c|c|}
\hline Sample & $\begin{array}{l}\text { Measured } \\
\text { parameter }\end{array}$ & $\begin{array}{c}\text { Short treatment } \\
\text { with S9 mix }\end{array}$ & $\begin{array}{l}\text { Long treatment } \\
\text { without } 59 \mathrm{mix}\end{array}$ \\
\hline \multirow{2}{*}{ Negative control } & \% cytotoxicity & $0 \%$ & $0 \%$ \\
\hline & $\mathrm{MN} / 1000 \mathrm{BNC}$ & 17 & 19 \\
\hline \multirow{2}{*}{$\begin{array}{l}\text { A2 negative control } \\
\text { (ethanol } 95 \%, 1 \% \text { ) }\end{array}$} & $\%$ cytotoxicity & $0 \%$ & $0 \%$ \\
\hline & $\mathrm{MN} / 1000 \mathrm{BNC}$ & 14 & 19 \\
\hline \multirow{2}{*}{ A2 extract (1\%) } & \% cytotoxicity & $4.42 \%$ & $6.89 \%$ \\
\hline & MN/1000 BNC & 20 & 18 \\
\hline \multirow{2}{*}{$\begin{array}{l}\text { A8 negative control } \\
\text { (ethanol } 10 \%, 1 \% \text { ) }\end{array}$} & $\%$ cytotoxicity & $0 \%$ & $0 \%$ \\
\hline & $\mathrm{MN} / 1000 \mathrm{BNC}$ & 18 & 17 \\
\hline \multirow{2}{*}{ A8 extract $(1 \%)$} & \% cytotoxicity & $3.39 \%$ & $3.33 \%$ \\
\hline & $\mathrm{MN} / 1000 \mathrm{BNC}$ & 19 & 16 \\
\hline \multirow{2}{*}{$\begin{array}{l}\text { Positive control } \\
\text { Cyclophosphamide } \\
(10 \mu \mathrm{g} / \mathrm{ml})\end{array}$} & $\%$ cytotoxicity & $15.48 \%$ & - \\
\hline & $\mathrm{MN} / 1000 \mathrm{BNC}$ & 58 & - \\
\hline \multirow{2}{*}{$\begin{array}{l}\text { Positive control } \\
\text { mitomycine C } \\
(25 \mathrm{ng} / \mathrm{ml}) \\
\end{array}$} & $\%$ cytotoxicity & - & $31.21 \%$ \\
\hline & $\mathrm{MN} / 1000 \mathrm{BNC}$ & - & 194 \\
\hline \multirow{2}{*}{$\begin{array}{l}\text { Positive control } \\
\text { vinblastine sulfate } \\
(0.625 \mathrm{ng} / \mathrm{ml})\end{array}$} & $\%$ cytotoxicity & - & $0.87 \%$ \\
\hline & $\mathrm{MN} / 1000 \mathrm{BNC}$ & - & 63 \\
\hline
\end{tabular}




\subsection{Endocrine disruption activity}

HepG2 were transiently co-transfected with ERE-TK-LUC and the hER $\alpha$ expression vector. $17 \beta$-estradiol (10 $\mathrm{nM})$ used as a positive reference, resulted in a significant induction of the reporter gene activity. The activity of the extracts $(13.5 \mathrm{mg} / \mathrm{mL}$ for $A 2$ and $41.5 \mathrm{mg} / \mathrm{mL}$ for A8) as well as that of the positive control were expressed relatively to the negative control. Under our experimental conditions, no statistically significant increase in ERa transcriptional activity was observed when HepG2 cells were exposed to A2 or A8 extracts (induction of 2 and 1.4 respectively compared to the negative control), suggesting that neither $A 2$ nor $A 8$ extract presents an agonist ERa estrogenic activity (Fig. 1).
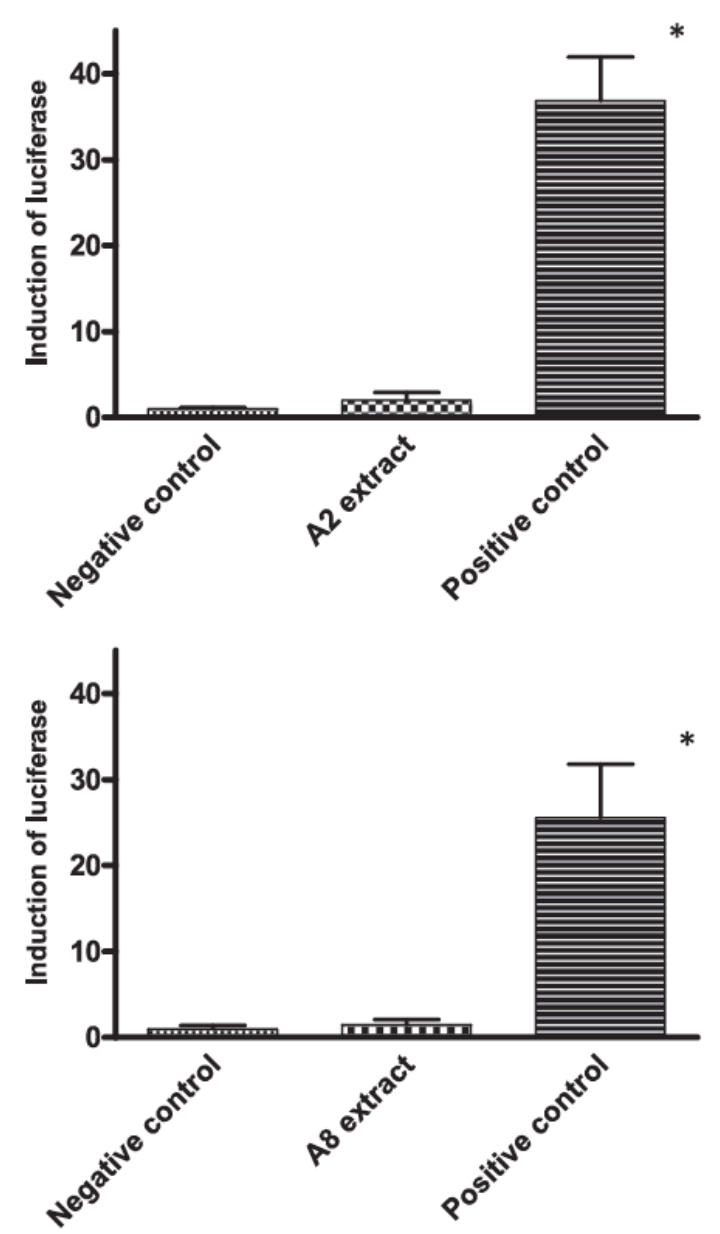

Figure 1. Estrogenic activity in HepG2 cell line exposed to $1 \%$ of $A 2$ or $A 8$ extracts $(13.5 \mathrm{mg} / \mathrm{mL}$ and 41.5 $\mathrm{mg} / \mathrm{mL}$ respectively). Ethanol $95 \%(\mathrm{v} / \mathrm{v})$ or ethanol $10 \%(\mathrm{v} / \mathrm{v})$ were used as negative control for respectively $\mathrm{A} 2$ and $\mathrm{A} 8$ extracts, $17 \mathrm{~b}$-estradiol $(10 \mathrm{nM})$ was used as positive control. The sign * indicates results statistically different from the negative control using a Fisher test. All experiments were performed in triplicate. 


\section{DISCUSSION}

The combination of negative results for all the toxicology tests performed indicates sufficient passivity to food stimulants for both types of coating. Several factors can be invoked to explain these results.

First, migration results strongly depend on both coating to substrate adhesion, and coating network cohesion. Regarding the latter, it should be noted that ORMOSILs are great sol-gel precursors for food-contact applications: unlike class I hybrid materials which show weak interactions between the organic and inorganic phases, ORMOSIL precursors display a strong covalent bond between the two parts which i) is maintained during the sol-gel reactions (soft chemistry) and ii) favors high cohesion and network connectivity of the coating, minimizing network depolymerization. With respect to adhesion, it is clear that a bad (i.e. low) coating to substrate adhesion will cause the coating to peel off during the solvent immersion associated with migration tests, leading to extremely high migration levels. In the present case, the adhesion to $P C$ of the coatings $\left(G_{c}\right.$, in $\left.J / \mathrm{m}^{2}\right)$ was previously measured by the Double Cantilever Beam technique ${ }^{11}$. While $A 2$ derived samples inherently show a relatively high and satisfying adhesion to $P C\left(G_{c}=3.2 \mathrm{~J} / \mathrm{m}^{2}\right)$, it is not the case of $A 8$ derived samples $\left(G_{c}=1.5 \mathrm{~J} / \mathrm{m}^{2}\right)$. Indeed, values above $3 \mathrm{~J} / \mathrm{m}^{2}$ are indicative of strong covalent bonds at the interface, whereas values below $3 \mathrm{~J} / \mathrm{m}^{2}$ imply that weak interactions are dominant at the film/PC interface, suggesting mechanical adhesion mainly. In order to improve the adhesion of $\mathrm{A} 8$ derived coatings to PC, we have previously shown that nitrogen based plasmas are extremely effective: when depositing $A 8$ sol on $\mathrm{N}_{2} / \mathrm{H}_{2}$ plasma treated PC, we observe a 15 fold increase in adhesion, with $G_{c}$ values higher than $20 \mathrm{~J} / \mathrm{m}^{2}$. This preliminary plasma treatment step is thus likely to have an important role in the low migration level detected.

Bioassays such as the regulatory Ames test and micronucleus assay or a transcriptional activation assay were performed on the extracts (as mixture of migrating substances) for which the migration is the highest. In these most stringent experimental conditions, all results were found negative, constituting promising initial results to further continue the development of these coatings. In such conditions, the hazard assessment is performed on finish materials as the extracts contain both the intentionally added substances (IAS) used to produce the PC sheet and the coating, but also the non-intentionally added substances (NIAS) formed during the test process. Indeed, all of the substances able to migrate or the 
mixture of these substances didn't give a mutagenic effect on bacteria, nor induced chromosomal damage on a human cell line.

In the case of $A 2$ derived samples, the negative results obtained were anticipated as i) we previously showed that MTES induces negative responses in the Ames test and micronucleus assay ${ }^{20}$ and ii) all other sol-gel reactants used in A2 synthesis are already EU or FDA approved substances. Regarding A8 derived samples, the negative results were not a foregone conclusion. Indeed, even if TEOS by itself was shown to be non-toxic, unreacted GPTES shows a mutagenic effect on bacteria in the Ames test ${ }^{20}$ due to its epoxy group, a well-known structural alert since it highly reacts with cell DNA. These negative results observed thus indicate that probably few or no unreacted GPTES molecules were present in the extracts, and two main assumptions can be made to explain it. The first one relates to epoxy reactivity: it is well-known that in presence of polar bonds such as $\mathrm{C}-\mathrm{NH}_{2}$, (formed on the PC surface during $\mathrm{N}_{2} / \mathrm{H}_{2}$ plasma treatment), epoxy rings can open ${ }^{26}$ and react with the latter, creating covalent bonds at the interface (Fig. 2). Therefore, in addition to improving the coating to substrate adhesion, the $\mathrm{N}_{2} / \mathrm{H}_{2}$ plasma treatment allows for epoxy group transformation which reduces the probability of observing mutagenic effect. Nonetheless, it is worth mentioning that even with a $\mathrm{N}_{2} / \mathrm{H}_{2}$ plasma treatment, the presence of unreacted epoxy groups in the coating cannot be ruled out: indeed, some of the GPTES molecules may not go to the interface to react with treated PC, but may instead be "trapped" in the bulk due to the reaction of GPTES hydrolysable functions (not involving epoxy groups) that lead to silica formation (Fig. 2). However, if the cohesion of the silica network is high enough and that no silica depolymerization occurs when the film is in contact with the aqueous food simulants involved in the migration tests, little or no epoxy groups will be present in the extracts, strongly limiting the risk to trigger positive responses in toxicology tests. The next step would then be to check if epoxy groups are present in the extracts using analytical methods, and to verify any release in an accelerated test at elevated temperature. 


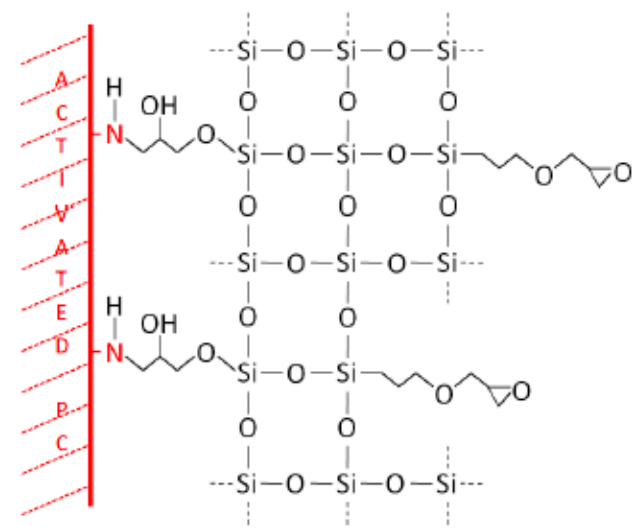

Figure 2. Illustration of the bulk and interface of A8 derived samples deposited on plasma treated polycarbonate.

In conclusion, migration and toxicity tests such as those required by the European regulation on food contact materials were carried out on two different sol-gel coating extracts derived from commonly used ORMOSILs (MTES, and GPTES/TEOS respectively) with the aim of gathering initial information on whether these coatings could be qualified as food grade materials. The low levels of migration measured on these coatings in the different food simulants (below the maximum authorized level), which translate into low coating weight loss ( $4 \%$ and $13 \%$ for $A 2$ and $A 8$ respectively), suggest excellent coating cohesion and adhesion to polycarbonate. Genotoxicity tests complying with EFSA specifications were then performed: for each coating, the extract which gives the maximum migration was selected to carry out the Ames test, micronucleus assay and endocrine disruption assay. None of the extracts triggered positive responses, indicating that both coatings are not mutagenic or clastogenic/aneugenic (damage on chromosomes) in such experimental conditions. Furthermore, no estrogenic activity was detected in vitro. These promising results clearly show the potential of these sol-gel coatings as food grade materials. Additional tests, such as chemical analyses, or release study, are on the way to obtain the complete characterization of the extracts and to claim $\mathrm{A} 2$ and $\mathrm{A} 8$ derived coatings as food grade materials.

\section{FUNDING SOURCES}

This work was supported by the "ministère de l'enseignement supérieur et de la recherche, le ministère de l'économie, de l'industrie et de l'emploi " (Fond Unique Interministériel Saveurs-Vapeurs 09290 6396). 


\section{References:}

(1) Wu, L. Y. L.; Chwa, E.; Chen, Z.; Zeng, X. T. Thin Solid Films 2008, 516, 1056-1062.

(2) Commission regulation (EU) No 10/20111 January 14th 2011, Plastic materials and articles intended to come into contact with food.

(3) Commission implementing regulation (EU) No 321/2011 April 1st 2011, amending Regulation (EU) No 10/2011 as regards the restriction of use of Bisphenol A in plastic infant feeding bottles.

(4) Fabbri, P.; Leonelli, C.; Messori, M.; Pilati, F.; Toselli, M.; Veronesi, P.; Morlat-Therias, S.; Rivaton, A.; Gardette, J. L. J Appl Polym Sci 2008, 108, 1426-1436.

(5) Li, Y.; Shimizu, H. Polym Eng Sci 2011, 51, 1437-1445.

(6) Zhang, W.; Li, X.; Guo, X.; Yang, R. Polym Degrad Stabil 2010, 95, 2541-2546.

(7) Bursikova, V.; Dvorak, P.; Zajickova, L.; Franta, D.; Janca, J.; Bursik, J.; Sobota, J.; Klapetek, P.; Blahova, O.; Perina, V. Optoelectron Adv Mat 2007, 1, 491-495.

(8) Damasceno, J. C.; Camargo, S. S.; Cremona, M. Thin Solid Films 2002, 420, 195-199.

(9) Schulz, U.; Lau, K.; Kaiser, N. Appl Optics 2008, 47, C83-C87.

(10) Cui, L.; Lionti, K.; Ranade, A.; Larson-Smith, K.; Dubois, G. J.-M.; Dauskardt, R. H. ACS Nano 2014, 8, 7186-7191.

(11) Lionti, K.; Cui, L.; Volksen, W.; Dauskardt, R.; Dubois, G.; Toury, B. ACS Appl Mater Interfaces 2013, 5, 11276-11280.

(12) Lionti, K.; Toury, B.; Boissiere, C.; Benayoun, S.; Miele, P. J Sol-Gel Sci Technol 2013, 65, 52-60.

(13) Le Bail, N.; Benayoun, S.; Toury, B. J Sol-Gel Sci Technol 2015, 75, 710-719.

(14) Le Bail, N.; Lionti, K.; Benayoun, S.; Pavan, S.; Thompson, L.; Gervais, C.; Dubois, G.; Toury, B. New J Chem 2015, accepted, DOI 10.1039/C1035NJ00426H.

(15) Sanchez, C.; Julian, B.; Belleville, P.; Popall, M. J Mater Chem 2005, 15, 3559-3592.

(16) Dubanchet, A.; Perillon, J.-L.; SEB, Ed. FR2915205A1, 2008.

(17) Jeon Bong, Y.; Kim Sang, M.; LTD, C. H. K., Ed. US2007218297A1, 2007.

(18) Chung Kwon, P.; LTD, S. w. t. C., Ed. WO2008010639A1, 2008.

(19) Toury, B.; Lionti, K.; Dubanchet, A.; Blond, L.; Miele, P.; Seb Sa, U. C. B. L., Centre National De La Recherche Scientifique-Cnrs, Ed. WO2014079947 A1, 2014.

(20) Lionti, K.; Severin, I.; Dahbi, L.; Toury, B.; Chagnon, M.-C. Food Chem Toxicol 2014, 65, 76-81.

(21) EFSA Note for guidance for Food Contact Materials 2008, p.125.

(22) Kirkland, D. J.; Marshall, R. R.; McEnaney, S.; Bidgood, J.; Rutter, A.; Mullineux, S. Mutat Res 1989, 214 , 115-122.

(23) Maron, D. M.; Ames, B. N. Mutat Res 1983, 113, 173-215.

(24) Kirsch-Volders, M.; Sofuni, T.; Aardema, M.; Albertini, S.; Eastmond, D.; Fenech, M.; Ishidate, M.; Lorge, E.; Norppa, H.; Surralles, J.; von der Hude, W.; Wakata, A. Environ Mol Mutagen 2000, 35, 167-172.

(25) Gasnier, C.; Dumont, C.; Benachour, N.; Clair, E.; Chagnon, M.-C.; Seralini, G.-E. Toxicology 2009, 262, 184-191.

(26) Innocenzi, P.; Kidchob, T.; Yoko, T. J Sol-Gel Sci Technol 2005, 35, 225-235. 